\title{
Study on Consistency of Salt Iodization in Salt Factories
}

\author{
S. A. Jabin* \\ Institute of Nutrition and Food Science, University of Dhaka, Dhaka-1000, Bangladesh
}

\begin{abstract}
The study was conducted among the salt factories located in four different zones-Narayangonj, Chittagong, Patiya and Khulna, who have SIP'S (Salt lodization Plant) and produce iodized Salts. A law was enacted which made the mixing of iodine at 45 to 50 ppm level mandatory to all the salt factories in Bangladesh. The objectives of the sutdy were to determine the iodine level of salts maintained by those factories situated in those four zones. Total 2352 samples were collected from 121 open and regularly operating salt factories. Analysis of results of salt samples showed that total 1338 (56.89\%) salts had inadequate iodine (<45 ppm), 175 (7.44\%) salts had adequate iodine (40 to $50 \mathrm{ppm}$ ) and 839 (35.67\%) salts contained higher amount of iodine ( $>50 \mathrm{ppm}$ ). Factory wise, $12.40 \%$ factories found producing salts containing inadequate level of iodine, 4.96\% factories found producing excess level of iodine, $47.93 \%$ factories found producing sometime high or low level of iodine (not adequate level at all) and 34.71\% factories found mixing iodine sometimes adequately and other time mixing either inadequately or excess level of iodine. So not a single factory out of 121 factories in those four zones maintains consistency in mixing iodine in iodized salt.)
\end{abstract}

Key words: Iodine, Iodized salt, Salt, Iodization plant, Salt factory, Consistency

\section{Introduction}

Bangladesh has major public health problems especially relating to micronutrient deficiencies. Iodine is one of the most important micronutrient deficiency of which causes Iodine Deficiency Disorder (IDD) resulting goiter, physical and mental handicap and poor educability of children. Globally more than 1.57 billion people are living in IDD endemic areas (Lathen, 1997). The picture in Bangladesh is particularly very grim. To combat the iodine deficiency disorders, the Government of Bangladesh has passed the Universal salt Iodization (USI) law in 1989 making it mandatory that all salts produced or imported must be iodized (Bangladesh Gazette, 1989) and accordingly installed Salt Iodisation Plants (SIP's) in all salt factories of the country. However, it is important to know whether salt is iodized properly and how efficient and effective the initiative is as a whole.

Earlier two separate quick surveys were carried out in 1996 and 1999 for evaluating the status of salt iodization program under a project name "Evaluation of Universal Salt Iodization" (USI) in Bangladesh (IDD News Letter, 1999), Under the said surveys salt samples were collected at random from all operating factories across the country, statistically from retail shops and households through out the coun- try. However, in these surveys the salt samples were coollected randomly for only one time from cach factory.

On the other hand, for this specific comprehensive study's, salts were collected for three months at a stretch with due deliberation on daily basis and as many times as the factories carried out their process and production.

The objectives of the study were to study the consistency of the factories, whether the salt factories are maintaining in mixing iodine in salts as per requirement of law.

\section{Materials and Methods}

The study period was July 2001 to June 2002. Salt samples were collected on daily basis trom 121 operating salt factories located in four different zoned- Narayangonj, Chittagong, Patiya and Khulna for three months as many times as they produced and processed. Salts were also collected from all types of storage like gola, packet and big sack. A total of 2352 salt samples were collected from 121 salt factories.

\footnotetext{
*Corresponding authour, E-mail: abshajabin@yahoo.co.in
} 
Salt samples were put in an individual disposable polythene bag, which was sealed off airtight and carried in cartons and brought to IDD laboratory at the Institute of Nutrition and Food Science (INFS), University of Dhaka. The samples were stored at room temperature until analysis.

In iodized salt, iodine is added in the from of potassium iodate $\left(\mathrm{KIO}_{3}\right)$. By addition of sulfuric acid, salt iodate is converted into iodine. Liberated iodine is trapped with the addition of potassium iodide. The free iodine is then titrated against sodium thiosulphate using starch as an external indicator (Karmarkar, et. al., 1986). The reaction is expressed as follows:

$$
\begin{array}{lll}
\mathrm{KIO}_{3}+5 \mathrm{KI}+3 \mathrm{H}_{2} \mathrm{SO}_{4} & \longrightarrow \mathrm{K}_{2} \mathrm{SO}_{4}+3 \mathrm{I} \mathrm{H}_{2} \mathrm{O} \\
\mathrm{KI}+\mathrm{I}_{2} & \longrightarrow \mathrm{KI}_{3} \\
\mathrm{Na}_{3} \mathrm{~S}_{2} \mathrm{O}_{3}+\mathrm{I}_{2} & \longrightarrow \mathrm{Nal}+\mathrm{Na}_{2} \mathrm{~S}_{4} \mathrm{O}_{6}
\end{array}
$$

\section{Results and Discussion}

Data presented in Table I gives the results of iodine content of salt samples collected from the salt factories located in four zones:
(>50 ppm). Among them 455 (54.0\%), 485 (57.3\%), 99 (49.7\%), and 299 (64.4\%) salt samples collected from Narayangonj, Chittagong,Patiya and Khulna respectively had inadequate iodine. Only 100 (11.9\%), 31 (3.7\%), $6(3.0 \%)$ and $38(8.2 \%)$ salt samples contained adequate iodine level, which were collected from Narayangonj, Chittagong,Patiya and Khulna respectively. 287 (34.2\%), 331 (39.0\%), 94 (11.2\%) and 127 (51.1\%) salt samples collected from Narayangonj, Chittagong, Patiya and Khulna had excess iodine.

The lowest iodine content in salt was found 3.17, 1.05, 4.11 and $2.12 \mathrm{ppm}$ in Narayangong, Chittagong, Patiya and Khulna respectively and the maximum iodine content was > 1000 ppm found in all four zones.

On the basis of factory only 42 (34.71\%) factories out of 121 factories were producing iodized salt as per law. 12.4\% factories mixed in adequate amount of iodine in salt, $5 \%$ facto-

\begin{tabular}{|c|c|c|c|c|c|}
\hline \multirow{2}{*}{$\begin{array}{l}\text { Name of the } \\
\text { salt mile } \\
\text { zone }\end{array}$} & \multirow{2}{*}{$\begin{array}{l}\text { No. of total } \\
\text { factory }\end{array}$} & \multirow{2}{*}{$\begin{array}{c}\text { Open and } \\
\text { produced } \\
\text { salt regularly }\end{array}$} & \multicolumn{3}{|c|}{ Salt iodine (ppm) } \\
\hline & & & $\begin{array}{l}\text { Inadequate } \\
(0.0-44.9)\end{array}$ & $\begin{array}{l}\text { Adequate* } \\
(45.0-50.0)\end{array}$ & $\begin{array}{l}\text { Excess } \\
(>50.0)\end{array}$ \\
\hline Narayangonj & 42 & 25 & 445 (54.0\%) & 100 (11.9\%) & 287 (34.2\%) \\
\hline Chittagong & 68 & 67 & 485 (57.3\%) & 31 (3.7\%) & 331 (39.5\%) \\
\hline Patiya & 29 & 17 & 99 (49.7\%) & $6(3.7 \%)$ & 94 (11.2\%) \\
\hline Khulna & 25 & 12 & 299 (64.4\%) & 38 (8.2\%) & 127 (51.1\%) \\
\hline Total & 164 & 121 & $\begin{array}{c}1338 \\
(56.89 \%)\end{array}$ & $\begin{array}{c}175 \\
(7.44 \%)\end{array}$ & $\begin{array}{c}839 \\
(35.67 \%)\end{array}$ \\
\hline
\end{tabular}
ries mixed excess and $47.9 \%$ factories shows inconsistency

Table I: Zone-wise distribution of factories and iodine content of salt Samples

*As per low 45-50 ppm iodine should be present in the iodized salt at the production site.

Analysis of the results of salt samples collected from the salt factories located in four zones showed that total 1338 salt samples (56.89\%) had inadequate iodine ( $<45 \mathrm{ppm}), 175$ samples (7.44\%) had adequate iodine (45 to $50 \mathrm{ppm}$ ) and 839 samples (35.67\%) contained higher amount of iodine in mixing iodine in salt. Factories producing salt containing adequate iodine also found producing salts with iodine level lower than adequate and higher than adequate levels. 
Table II. The Picture of Iodine Level in the Factories Mixing Iodine in Four Different Zones

\begin{tabular}{|c|c|c|c|c|}
\hline \multirow[t]{2}{*}{ Category } & \multicolumn{4}{|c|}{ No. of factories } \\
\hline & Narayangonj & Chittagong & Patiya & Khulna \\
\hline $\begin{array}{l}\text { Inadequate } \\
(0.0-44.9 \mathrm{ppm} \\
\text { iodine) }\end{array}$ & $6(24.0 \%)$ & $5(7.5 \%)$ & 2 (11.8\%) & $2(16.7 \%)$ \\
\hline $\begin{array}{l}\text { Adequate } \\
\text { (45.0-50.0 ppm } \\
\text { iodine) }\end{array}$ & $10(40.0 \%)$ & 24 (35.8\%) & $4(23.5 \%)$ & $4(33.3 \%)$ \\
\hline $\begin{array}{l}\text { Excess (>50.0 } \\
\text { ppm iodine) }\end{array}$ & $1(4.0 \%)$ & 3 (4.5\%) & $1(5.9 \%)$ & $1(8.3 \%)$ \\
\hline $\begin{array}{l}\text { Mixed } \\
\text { (High \& Low) }\end{array}$ & $8(32.0 \%)$ & 35 (52.2\%) & 10 (58.8\%) & $5(41.7 \%)$ \\
\hline Total & 25 (100\%) & 67 (100\%) & 17 (100\%) & $12(100 \%)$ \\
\hline
\end{tabular}

To study the consistency of salt factories about producing iodized salt or mixing iodine as per law, average iodine content were checked. Mean iodine level (Std.dev) for three months were 107.46 (169.43), 218.96 (202.43), 159.66 (199.87) and 75.54 (110.28) in Narayangonj, Chittagong, Patiya and Khulna respectively.

Immediately after processing and mixing iodine, salts are piled up as gola and then packed and sacked for distribution. Maximum level of iodine retention is expected in Gola because salts are pilled up immediately after mixing of iodine. Packed should contain the level of iodine close to the gola but not more. Sack may lose iodine to some extent because of the type and nature of its packing. The mean iodine of the 927 salt samples collected from gola, after iodization and before packing was 116.88 ppm, 664 salts from packet ( $1 \mathrm{~kg}$ or $1 / 2 \mathrm{~kg}$ ) was $96.42 \mathrm{ppm}$ and 744 salts from $75 \mathrm{~kg}$ big sac was $107.10 \mathrm{ppm}$.

It is important to monitor whether the iodized salt produced and sold in the market contains the specific quantities of iodine as per law ie. $45-50 \mathrm{ppm}$ at the production level, 20 ppm at the retail shop level and a minimum of $15 \mathrm{ppm}$ at the consumption level. Among all the levels production level is most important, because if iodine content in salt is maintained as per repuirement at production level, subsequent iodine levels from retail shop to household would contain the intended level of iodine.

\section{Conclusion}

From the experimental data it may be concluded that, no factory producing iodized salt properly all the time. Even the same factory is producing iodized salt containing different amount of iodine in a day or in a week. The reason may be either the factories are not serious (adding different amount of potassium iodate to different amount of water for mixing before spraying to salt) or the spray of potassium iodate and water mixture is not properly done (problem in spray in SIP)

\section{References}

Bangladesh Gazette. (1989) Iodine Deficiency Disease Prevention Act.

IDD News Letter (1999) Evaluation of Universal Salt Iodization in Bangladesh- 4:1. pp.9. 
IPHN/ BSCIS/ UNICEF/ ICCIDD. December (1996) Evaluation of Universal Salt Iodization (USI) in Bangladesh- pp. 9-10.

Karmarkar M. G. C. S., Pandav K. A. V. R, and Krishnamachari. (1986) Principal and Procedure for Iodine Estimation-A Laboratory Manual. Indian Council for Medical Reseach. New Delhi.
Lathen M. C. (1997) Iodine Deficiency Disorder in Human Nutrition in the Developing World, FAO Rome: pp. 157-163.

Received : June, 08, 2008;

Accepted : November 06, 2008 